\title{
Genotypic variability in phosphorus solubilizing activity of root exudates by pigeonpea grown in low-nutrient environments
}

\author{
S. Ishikawa ${ }^{1,4,5}$, J. J. Adu-Gyamfi ${ }^{1}$, T. Nakamura ${ }^{2}$, T. Yoshihara $^{3}$, T. Watanabe ${ }^{3}$ \& \\ T. Wagatsuma ${ }^{4}$ \\ ${ }^{1}$ International Crops Research Institute for the Semi Arid Tropics (ICRISAT), Sabo Bakin Zuwo Road, PMB 3491, \\ Kano, Nigeria. ${ }^{2}$ Japan International Research Center for Agricultural Sciences (JIRCAS), 1-2 Ohwashi, Tsukuba, \\ Ibaraki, 305-8686, Japan. ${ }^{3}$ Faculty of Agriculture, Hokkaido University, Sapporo, Hokkaido, 060-8589, Japan. \\ ${ }^{4}$ Faculty of Agriculture, Yamagata University, Tsuruoka, Yamagata, 997-8555, Japan. ${ }^{5}$ Corresponding author*
}

Received 10 May 2000. Accepted in revised form 24 October 2000

Key words: Alfisols, phosphorus deficiency, phosphorus solubilization, pigeonpea genotype, piscidic acid, root exudates

\begin{abstract}
A pot experiment confirmed that pigeonpea could efficiently utilize various sources of phosphorus (P) (aluminium phosphate, iron phosphate and apatite), irrespective of genotype. A qualitative assay method for iron (Fe)-P solubilizing activity showed that root exudates collected from P-deficient pigeonpea contained Fe-P solubilizing substances and that they were released mainly from root tips. Citric, malic, malonic, succinic and piscidic acids were identified in root exudates. Citric and piscidic acids release from roots was increased by low-P treatment in all the genotypes tested. The release rates of citric and piscidic acids were affected by the $\mathrm{P}$ concentration of shoots rather than that of roots. The pigeonpea roots released approximately 5-100 times more piscidic acid than citric acid depending on $\mathrm{P}$ stress status, plant age and genotype. When organic acids were added to Alfisols, citric acid was most capable of mobilizing $\mathrm{P}$ from the soil, followed by piscidic acid and malic acid. No correlation was found between genotypic variability in the release rates of citric and piscidic acids from the roots under low-P treatment at hydroponic culture and in the growth and $\mathrm{P}$ uptake of plants on Alfisols. Although citric and piscidic acids released from pigeonpea roots may play a partial role in solubilizing unavailable insoluble $\mathrm{P}$ in soils, the releases were thought to be an unsatisfactory strategy for explaining genotypic variation in low $\mathrm{P}$ availability of pigeonpea.
\end{abstract}

\section{Introduction}

Many tropical and subtropical soils with high levels of iron (Fe) and aluminium ( $\mathrm{Al}$ ) oxides have extremely high capacities to immobilize phosphorus $(\mathrm{P})$ and render it unavailable for uptake by plants. However, it has been found that several plant species are able to directly modify the rhizosphere in order to acquire and utilize unavailable soil-P compounds (Jones, 1998; Rengel, 1999). The release of organic acids from roots that is induced by $\mathrm{P}$ deficiency is an effect-

\footnotetext{
* FAX No: +81-235-28-2812. Tel.: +81-235-28-2917.

E-mail: isatoru@tds1.tr.yamagata-u.ac.jp
}

ive way for plants to acquire sparingly soluble $\mathrm{P}$ from soils. Investigations using white lupin (Lupinus albus L.) showed that the amount of citrate excreted under P-deficiency was as much as $12 \%$ of the total plant dry weight (Gardner et al., 1983), and that proteoid roots exuded larger amounts of citrate and malate than normal roots (Johnson et al., 1996). Hoffland (1992) reported that $\mathrm{P}$ uptake from rock phosphate by rape (Brassica napus L.) increased by acidifying part of the rhizosphere by exuding of citric and malic acids. Ohwaki and Hirata (1992) compared the differences in carboxylic acid exudation among six tropical leguminous crops subjected to $\mathrm{P}$ starvation, and found that larger amounts of citric and malic acids were exuded 
from the roots of chickpea than those exuded by other leguminous crops. Thus, citric and malic acids were identified as the primary carboxylic acid released from the roots of many plant species under P-starvation.

Pigeonpea [Cajanus cajan (L.) Millsp] is an important leguminous crop and a protein source for people living in semi-arid tropics (SAT). Ae et al. (1990) reported that pigeonpea is more able to utilize Fe-P than several cereals and other leguminous crops because it can exude piscidic acid from its roots. Piscidic acid is a new substance reported in root exudates of P-deficient plants, it differs from such carboxylic acids as citric and malic acids because it is a phenolic compounds (Toshima et al., 1999; Yoshihara et al., 1971). The few reports on genotypic variation in P-solubilizing activity of pigeonpea root exudates in low-P environments (Subbarao et al., 1997a, b) did not show a correlation between genotypic differences in the release rates of carboxylic acids (including piscidic) from pigeonpea roots in response to low-P environments, or in the acquisition of $\mathrm{P}$ from soils where it was scarce.

The purpose of this study was to analyze the $\mathrm{P}$ acquisition mechanisms implicated in organic acids released from the roots of pigeonpea genotypes to provide information useful in breeding crop ideotypes that could utilize unavailable $\mathrm{P}$ more efficiently than the present pigeonpea genotypes. The exploitation of plant genetic variation in the acquisition of unavailable insoluble $\mathrm{P}$ in soils is emerging as an alternate approach to improve productivity in low-nutrient environments. If successful, it would result in low-input and sustainable agriculture systems in the SAT.

\section{Materials and methods}

\section{Comparison of $P$ utilization from different sources of $P$ among pigeonpea genotypes}

A pot experiment was carried out at the International Crops Research Institute for the Semi-Arid Tropics (ICRISAT), Patancheru, Andhra Pradesh, India. The experiment was a randomized complete block design with four replicates. Four pigeonpea genotypes consisting of a hybrid (ICPH 8), a improved variety (ICPL 87), a local variety (Manak) and a droughttolerant line (ICPL 88039) were obtained from an initial screening of 15 genotypes (Adu-Gyamfi et al., 2000). The genotypes used were of extra-shortduration (maturity period $<110 \mathrm{~d}$ ) or short-duration (maturity period $<120-140 \mathrm{~d}$ ). Four different forms of fertilizers; aluminium phosphate $\left(\mathrm{AlPO}_{4}\right)$, iron phosphate $\left(\mathrm{FePO}_{4} \cdot \mathrm{H}_{2} \mathrm{O}\right)$, apatite $\left[\mathrm{Ca}_{5} \mathrm{OH}\left(\mathrm{PO}_{4}\right)_{3}\right]$ and single superphosphate (SSP) were applied at sowing; all provided $40 \mathrm{mg} \mathrm{P} \mathrm{kg}^{-1}$ soil. There was also a control (no $\mathrm{P}$ applied; $\mathrm{P}_{0}$ ). To remove the water-soluble $\mathrm{P}$ fraction in the $\mathrm{AlPO}_{4}$ and $\mathrm{FePO}_{4} \cdot \mathrm{H}_{2} \mathrm{O}$, they were washed in distilled water several times and dried in an oven at $80{ }^{\circ} \mathrm{C}$ before mixing with the soil. Each of the $\mathrm{P}$ sources with $50 \mathrm{mg} \mathrm{N} \mathrm{kg}^{-1}$ soil were mixed with $10 \mathrm{~kg}$ soil (Alfisol) and the mixtures used to fill pots. Five seeds of pigeonpea were sown in each pot and adequate deionized water was supplied when required. The seedlings were thinned to 1 per pot after emergence. Plants were harvested at the beginning of the flowering stage (60 days after sowing). Plants were separated into leaves, stems and roots, dried to a constant weight and weighed. The $\mathrm{P}$ concentrations in the tissues were determined by a molybdenum-ascorbic acid method (Murphy and Riley, 1962) after digestion with $\mathrm{H}_{2} \mathrm{SO}_{4}$ and $\mathrm{H}_{2} \mathrm{O}_{2}(2: 5 \mathrm{v} / \mathrm{v})$. Available $\mathrm{P}$ in the soil was estimated using Troug and Bray II, and inorganic and insoluble $\mathrm{P}$ forms (Al-P, Ca-P and Fe-P) were estimated by the method of Sekiya (1983) before sowing and after harvest.

\section{Plant preparation for collection of root exudates}

In another experiment, the seeds of the same pigeonpea varieties were sown in sand and grown for 14 days with deionized water only. Seedlings were washed from the sand culture and carefully transferred to two 600-L tubs containing nutrient solution of the following composition $(\mu \mathrm{M})$ : $\mathrm{N} 1000\left(\mathrm{NH}_{4} \mathrm{NO}_{3}\right), \mathrm{K} 500$ $\left(\mathrm{KCl}: \mathrm{K}_{2} \mathrm{SO}_{4}[1: 1]\right), \mathrm{Ca} 750\left(\mathrm{CaCl}_{2} \cdot \mathrm{H}_{2} \mathrm{O}\right), \mathrm{Mg} 500$ $\left(\mathrm{MgSO}_{4} \cdot \mathrm{H}_{2} \mathrm{O}\right), \mathrm{Fe} 18\left(\mathrm{FeSO}_{4} \cdot 7 \mathrm{H}_{2} \mathrm{O}\right), \mathrm{B} 46\left(\mathrm{H}_{3} \mathrm{BO}_{3}\right)$, Mn $0.9\left(\mathrm{MnCl}_{2} \cdot 4 \mathrm{H}_{2} \mathrm{O}\right), \mathrm{Cu} 0.16\left(\mathrm{CuSO}_{4} \cdot 5 \mathrm{H}_{2} \mathrm{O}\right), \mathrm{Zn}$ $0.15\left(\mathrm{ZnSO}_{4} \cdot 7 \mathrm{H}_{2} \mathrm{O}\right)$, Mo $0.1\left(\mathrm{NaMoO}_{4} \cdot 2 \mathrm{H}_{2} \mathrm{O}\right)$ and Co $0.001\left(\mathrm{CoSO}_{4}\right)$. The $\mathrm{P}$ concentrations in nutrient solution were 2 or $80 \mu \mathrm{M} \mathrm{P}$ as $\mathrm{KH}_{2} \mathrm{PO}_{4}$. To simplify the terminology, 2 and $80 \mu \mathrm{M} \mathrm{P}$ were designated as low-P and high-P. The 600-L tubs was covered with an aluminium sheet with 100 holes (10 rows and 10 columns). One tub was used for each P treatment and the four genotypes were randomized and transplanted in two rows per genotype. The solutions were continually aerated, refreshed with new solutions once a week and their $\mathrm{pH}$ was adjusted to 5.3 every day. These seedlings were grown in a greenhouse regulated at a constant temperature of $30^{\circ} \mathrm{C}$ under natural light conditions. After 15 days, the $\mathrm{P}$ concentration in the 
low-P treatment was increased to $4 \mu \mathrm{M}$ to prevent the plants from dying of severe $\mathrm{P}$ deficiency. At 15 or 30 days after transplanting, four uniform seedlings of each genotype were taken from the tub, their seedlings were washed thoroughly in distilled water and transferred to a $1-\mathrm{L}$ plastic container of $1 \mathrm{mM} \mathrm{CaCl}_{2}$ solution at $\mathrm{pH}$ 5.3. Root exudates were collected for $24 \mathrm{~h}$ under aeration in a growth chamber at $27^{\circ} \mathrm{C}, 16$ /8-h day/night cycles, $70 \mathrm{~W} \mathrm{~m}^{-2}$ light intensity and $70 \%$ relative humidity. The solutions containing root exudates were passed through filter paper (No. 6) and concentrated to approximately $5 \mathrm{~mL}$ using a rotary evaporator at $40{ }^{\circ} \mathrm{C}$. Samples were stored at $-20{ }^{\circ} \mathrm{C}$ until organic acid analysis.

To examine the change in the release rate of organic acid from roots depending on change in internal $\mathrm{P}$ concentration, seedlings pre-exposed to low-P solution for 15 days were transferred to low-P or high$\mathrm{P}$ nutrient solutions and incubated for 7 days. The collection of root exudates and determination of the $\mathrm{P}$ concentrations in shoots and roots were done as described above.

In order to examine the effect of temperature on the release of organic acid from the roots, four seedlings grown in low-P solution for 15 days were transferred to a 1 -L plastic container containing $1 \mathrm{mM} \mathrm{CaCl}_{2}$ solution. The containers were put into two water baths that were continuously maintained at $25^{\circ} \mathrm{C}$ or $35^{\circ} \mathrm{C}$ and incubated in a growth chamber at $25^{\circ} \mathrm{C}$ for $24 \mathrm{~h}$. The solution containing root exudates was concentrated as above and stored until organic acid analysis. All experiments on organic acid analysis were repeated twice.

\section{Assay method for Fe-P solubilizing activity}

In order to examine the Fe-P solubilizing activity by root exudates, a rapid and simple assay method was developed by modifying the method of Ma et al. (1997) for Al-chelating assay. Filter paper of adequate size (No.1) was immersed in $5 \mathrm{mM} \mathrm{FeCl}_{3}$ solution for $10 \mathrm{~min}$, then soaked in $1 / 15 \mathrm{M}$ phosphate buffer $(\mathrm{pH}$ 6.8 ) for $10 \mathrm{~min}$. The paper was washed in distilled water for several seconds and dried at $80{ }^{\circ} \mathrm{C}$. Each of the organic acids (citric, malic, succinic and piscidic acids) were dissolved in $0.5 \mathrm{M}$ acetate buffer $(\mathrm{pH}$ 4.5 ) and $2 \mu \mathrm{L}$ of each organic acid concentration ( 0 $0.5 \mathrm{M}$ ) dropped onto the paper. After $3 \mathrm{~min}$, the paper was washed in distilled water for several seconds and placed in $4 \%$ ammonium molybdate solution. After $5 \mathrm{~min}$, the paper was taken from the solution and covered with a new paper, which had been permeated with $1.6 \%$ ascorbic acid solution, that turned the lower paper blue. White spots on the blue lower paper were visible if solution samples were able to solubilize $\mathrm{Fe}-\mathrm{P}$ and phosphates were removed by washing with distilled water from the lower paper. Root exudate samples collected from roots treated with low-P for 30 days were also tested using the same method.

\section{Identification of the release portion of $\mathrm{Fe}-\mathrm{P}$ solubilizing substances}

A nondestructive technique was used to identify the part of the root that could release Fe-P solubilizing substances by modifying the method of Zheng et al. (1998) for Al-chelating substances. The roots of Manak seedling that was exposed to low-P for 30 days in hydroponic culture were put between filter papers permeated with $\mathrm{FePO}_{4}$ solution. Wet sponges containing distilled water were put above and below the filter papers to prevent the roots drying out. The Pstressed seedling was incubated in a growth chamber at $27^{\circ} \mathrm{C}$. After $24 \mathrm{~h}$, the seedling was removed, and the lower paper was washed in distilled water for several seconds. The paper was stained with ammonium molybdate and ascorbic acid solution as described above.

\section{Determination of organic acids}

All the root exudate samples collected from pigeonpea genotypes grown in solution culture as described above were passed through a cation exchange resin consisting of Dowex 50WX8-400 (200-400 mesh, $\mathrm{H}^{+}$ form) and then through an anion exchange resin consisting of Dowex 1X8-400 (200-400 mesh, $\mathrm{HCOO}^{-}$ form). The anionic fraction was eluted with $5 \mathrm{M}$ $\mathrm{HCOOH}$ and evaporated to dryness using a rotary evaporator at $40{ }^{\circ} \mathrm{C}$. The residue was dissolved in 1 $\mathrm{mL}$ dilute $\mathrm{H}_{2} \mathrm{SO}_{4}$ and passed through a membrane filter $(0.45 \mu \mathrm{m})$. The organic acid (citric, malic, malonic, succinic and piscidic) concentrations in root exudates were determined by HPLC equipped with an ion-exclusion column. Piscidic acid [(+)- $(2 S, 3 R)-]$ was synthesized from 4-hydroxyphenyl-pyruvic acid (Toshima et al., 1999) and used as a standard.

\section{Extraction efficiency of unavailable insoluble $P$ in Alfisol by organic acids}

The amount of phosphate released into solution by each organic acid (citric, malic, succinic and piscidic 

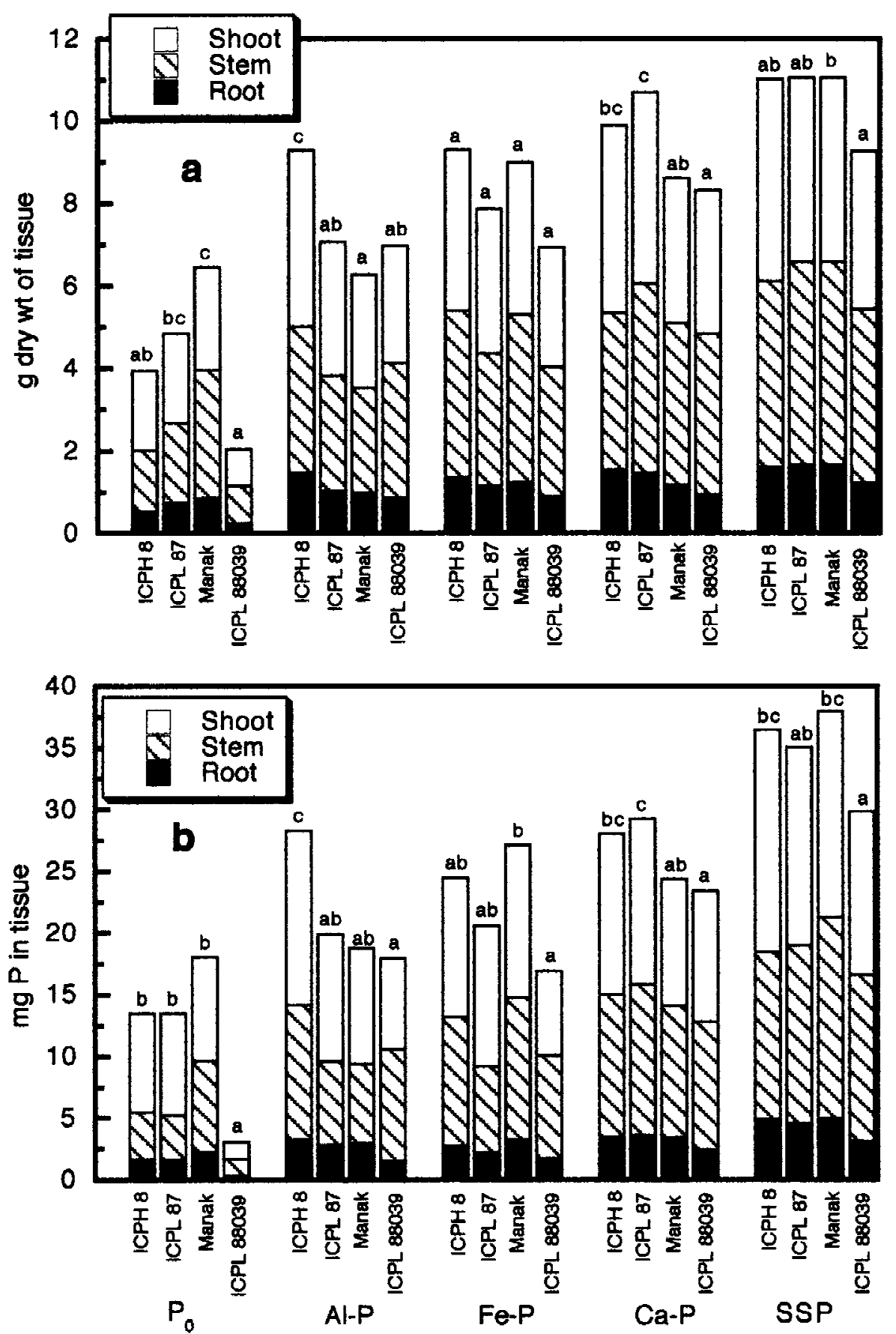

Figure 1. Comparison of dry weight (a) and $\mathrm{P}$ content (b) of plant tissues grown on an Alfisol applied with different $\mathrm{P}$ sources; $\mathrm{AlPO}_{4}(\mathrm{Al}-\mathrm{P})$, $\mathrm{FePO}_{4} \cdot \mathrm{H}_{2} \mathrm{O}(\mathrm{Fe}-\mathrm{P})$, apatite $(\mathrm{Ca}-\mathrm{P})$, single superphosphate (SSP) and no $\mathrm{P}$ added $\left(\mathrm{P}_{0}\right)$, among four pigeonpea genotypes. Plants were harvested at the beginning of the flowering stage. Each column represents the mean of four replications. Different letters indicate statistical difference $(P<0.05)$ among genotypes in each treatment. Duncan's Multiple Range Test was performed to separate the means. 
acid) was assessed by extracting $1 \mathrm{~g}$ of Alfisol with $10 \mathrm{~mL}$ of each organic acid solution $(\mathrm{pH} 4.5)$ at concentrations ranging between 0 and $5 \mathrm{mM}$ according to Jones and Darrah (1994). After shaking for $60 \mathrm{~min}$, samples were centrifuged at $2000 \mathrm{~g}$ for $10 \mathrm{~min}$ and the solutions were passed through filter paper (No. 6). As organic acids disturb the developing color of $\mathrm{P}$, the solution samples were evaporated to dryness on a hot plate $\left(180{ }^{\circ} \mathrm{C}\right)$, digested by $\mathrm{HNO}_{3}$ and $\mathrm{HClO}_{4}(5: 1$ $\mathrm{v} / \mathrm{v})$, and re-evaporated. The $\mathrm{P}$ concentration in the digests were estimated by the molybdenum-ascorbic acid method.

\section{Results}

The characteristics of the Alfisol used in this pot experiment before and after application of $\mathrm{P}$ from different sources are shown in Table 1. There was significantly more Fe-bound $\mathrm{P}$ in Alfisol without $\mathrm{P}$ fertilizer application, followed by Ca-P and Al-P. The $\mathrm{pH}$ was decreased slightly by applying SSP and was not affected by the other $\mathrm{P}$ sources. Approximately 70$80 \%$ of $\mathrm{Ca}_{5} \mathrm{OH}\left(\mathrm{PO}_{4}\right)_{3}$ added was detected as available $\mathrm{P}$ by both methods, whereas approximately $40-45 \%$ of $\mathrm{AlPO}_{4}$ and $\mathrm{FePO}_{4} \cdot \mathrm{H}_{2} \mathrm{O}$ added was detected as available $\mathrm{P}$ by Bray II method. Most $\mathrm{Ca}_{5} \mathrm{OH}\left(\mathrm{PO}_{4}\right)_{3}$ added was detected in $\mathrm{Ca}-\mathrm{P}$ fraction, but the added $\mathrm{AlPO}_{4}$ was hardly detected in the Al-P fraction and nor $\mathrm{FePO}_{4} \cdot \mathrm{H}_{2} \mathrm{O}$ in the $\mathrm{Fe}-\mathrm{P}$ fraction.

The total dry weight and total $\mathrm{P}$ content of the plant tissues in all the genotypes except for Manak were in the order of $\mathrm{P}_{0}<\mathrm{Al}-\mathrm{P}, \mathrm{Fe}-\mathrm{P}<\mathrm{Ca}-\mathrm{P}<\mathrm{SSP}$ and those of Manak were in the order of $\mathrm{P}_{0}, \mathrm{Al}-\mathrm{P}<\mathrm{Ca}$ $\mathrm{P}<\mathrm{Fe}-\mathrm{P}<\mathrm{SSP}$ (Figure 1a, b). Similar results were reported by Fujita et al. (1995). The dry weight and $P$ contents of each tissue from Manak in the $\mathrm{P}_{0}$ and Fe-P treatments were higher than the other genotypes. In all treatments, ICPL 88039 had the lowest the dry weight and $\mathrm{P}$ content in all its tissues, and this difference was significant under $\mathrm{P}_{0}$ application. The $\mathrm{P}$ available in soils after cultivating pigeonpea genotypes under $\mathrm{P}_{0}$ application showed an increasing trend compared to the soil before cultivation and the soil without any plants for 60 days but supplied with deionized water (Figure 2).

The Fe-P on filter paper was hardly solubilized by low $\mathrm{pH}$ at 4.5 and acetate buffer (Figure 3a). Citric acid had the highest Fe-P solubilizing activity among organic acids tested (Figure $3 \mathrm{a}-\mathrm{f}$ ). Two $\mu \mathrm{L}$ of $5 \mathrm{mM}$ of citric acid, i.e. $10 \mathrm{nmol}$ was the minimum detectable

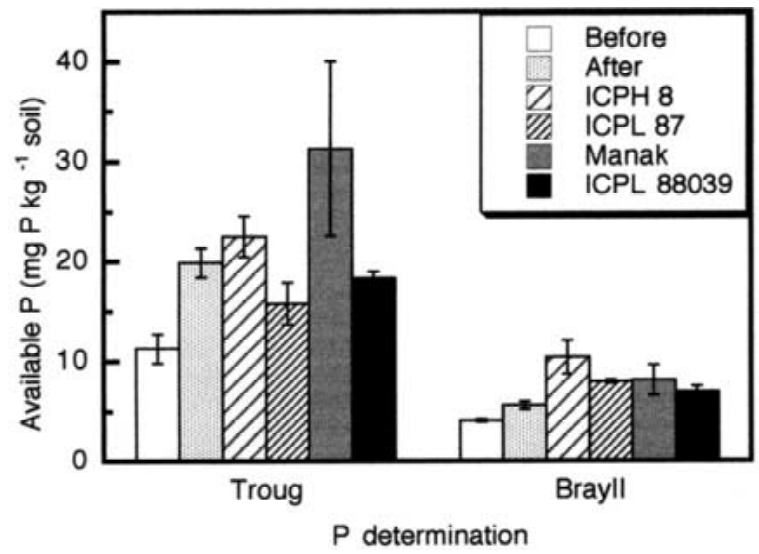

Figure 2. Available $\mathrm{P}$ in an Alfisol before and after cultivation. After cultivation of pigeonpea genotypes on an Alfisol without application of $\mathrm{P}\left(\mathrm{P}_{0}\right)$, available $\mathrm{P}$ was determined by both Troug and Bray II methods. The data were compared with $\mathrm{P}$ available in the soil before cultivation (Before) and that of a pot of soil retained without any plants for 60 days supplied with water (After). The columns and vertical bars represent the means and the standard errors in four replications.

concentration (Figure 3b). Different detectable limits were observed among organic acids. Twenty nmol of malic acid and piscidic acid were detectable (data not shown), but $1 \mu \mathrm{mol}$ of succinic acid (Figure 3f) was hardly detectable. A white spot on the filter paper was observed when Manak seedlings were grown in low$\mathrm{P}$ conditions, indicating that root exudates contained Fe-P solubilizing substances (Figure $3 \mathrm{~g}$ ). The solubilizing activity of $\mathrm{Fe}-\mathrm{P}$ was hardly detected in the other genotypes (data not shown). The extensive white spots were observed at approximately 2-cm from root-tips of Manak, indicating that Fe-P solubilizing substances was released mainly from root-tips (Figure $3 \mathrm{~h}$ ).

The release rates of citric and piscidic acids were increased with low-P treatment for both 15 and 30 days in all the genotypes except for some data of Manak (Table 2). There was approximately 3-fold difference in the citric acid release between the low-P and high-P treatments after 15 days in all genotypes except for ICPL 87 . The piscidic acid released by genotypes following low-P treatment for 15 days was slightly higher than that of high-P treatment except for Manak. The organic acid release after 30 days decreased as compared with that after 15 days because of increased external $\mathrm{P}$ concentration at low-P treatment. Nevertheless, approximately 2-fold difference in piscidic acid release was observed between treatments at 30 days. There was no significant differences in the amounts of succinic, malic and malonic acids released from 
Table 1. Chemical characteristics of Alfisols mixed with various P sources in a pot experiment. Values are means $(n=3)$ with standard error in parentheses

\begin{tabular}{|c|c|c|c|c|c|c|}
\hline \multirow[t]{2}{*}{ P sources } & \multirow{2}{*}{$\frac{\mathrm{pH}}{\left(\mathrm{H}_{2} \mathrm{O}\right)}$} & \multicolumn{2}{|c|}{ Available $\mathrm{P}\left(\mathrm{mg} \mathrm{kg}^{-1}\right.$ soil $)$} & \multicolumn{3}{|c|}{ Inorganic $\mathrm{P}\left(\mathrm{mg} \mathrm{kg}^{-1}\right.$ soil $)$} \\
\hline & & Troug & Bray II & $\overline{\mathrm{Al}-\mathrm{P}}$ & Ca-P & Fe-P \\
\hline $\mathrm{P}_{0}$ & 6.2 & $11.2(1.47)$ & $4.1(0.13)$ & $2.1(0.41)$ & $13.5(1.07)$ & $34.7(0.36)$ \\
\hline SSP & 6.0 & $18.7(0.42)$ & $13.4(1.55)$ & $1.2(0.95)$ & $13.9(2.91)$ & 41.5 (2.79) \\
\hline $\mathrm{AlPO}_{4}$ & 6.2 & $11.9(1.98)$ & $22.0(1.62)$ & $2.1(1.26)$ & $10.2(0.81)$ & $52.6(4.81)$ \\
\hline $\mathrm{Ca}_{5} \mathrm{OH}\left(\mathrm{PO}_{4}\right)_{3}$ & 6.2 & $42.4(0.48)$ & $31.0(1.85)$ & $0.8(0.55)$ & $41.7(2.91)$ & $46.7(3.12)$ \\
\hline $\mathrm{FePO}_{4} \cdot \mathrm{H}_{2} \mathrm{O}$ & 6.2 & $13.4(1.05)$ & $20.3(0.49)$ & $3.1(1.24)$ & $17.9(1.85)$ & $50.0(4.19)$ \\
\hline
\end{tabular}

Table 2. Effect of external P concentration and the treatment period on the release rates of citric and piscidic acids from the roots of pigeonpea genotypes

\begin{tabular}{|c|c|c|c|c|}
\hline Genotype & $\frac{\mathrm{P} \text { treatment }}{(\mu \mathrm{M} \mathrm{P})}$ & $\frac{\text { Period }}{\text { (days) }}$ & $\frac{\text { Citric acid }}{\left(\mu \mathrm{mol} \mathrm{g}^{-1}\right.}$ & $\frac{\text { Piscidic acid }}{\left.\text { t dry wt } 24 \mathrm{~h}^{-1}\right)}$ \\
\hline \multirow[t]{6}{*}{ ICPH 8} & 2 & 15 & $0.182(0.01)$ & $0.942(0.01)$ \\
\hline & 80 & & $0.067(0.05)$ & $0.739(0.13)$ \\
\hline & low $\mathrm{P} /$ high $\mathrm{P}$ & & 2.72 & 1.27 \\
\hline & 4 & 30 & $0.091(0.01)$ & $0.425(0.06)$ \\
\hline & 80 & & $\mathrm{ND}^{a}$ & $0.183(0.03)$ \\
\hline & low $\mathrm{P} /$ high $\mathrm{P}$ & & & 2.32 \\
\hline \multirow[t]{6}{*}{ ICPL 87} & 2 & 15 & $0.097(0.05)$ & $0.875(0.34)$ \\
\hline & 80 & & $0.071(0.04)$ & $0.674(0.11)$ \\
\hline & low $\mathrm{P} /$ high $\mathrm{P}$ & & 1.37 & 1.30 \\
\hline & 4 & 30 & $0.114(0.02)$ & $0.364(0.04)$ \\
\hline & 80 & & $0.040(0.04)$ & $0.190(0.02)$ \\
\hline & low $\mathrm{P} /$ high $\mathrm{P}$ & & 2.85 & 1.92 \\
\hline \multirow[t]{6}{*}{ Manak } & 2 & 15 & $0.178(0.03)$ & $0.801(0.06)$ \\
\hline & 80 & & $0.071(0.07)$ & $1.01(0.07)$ \\
\hline & low $\mathrm{P} /$ high $\mathrm{P}$ & & 2.50 & 0.79 \\
\hline & 4 & 30 & $0.102(0.01)$ & $0.403(0.03)$ \\
\hline & 80 & & $0.127(0.07)$ & $0.220(0.06)$ \\
\hline & low $\mathrm{P} /$ high $\mathrm{P}$ & & 0.80 & 1.83 \\
\hline \multirow[t]{6}{*}{ ICPL 88039} & 2 & 15 & $0.190(0.01)$ & $1.05(0.09)$ \\
\hline & 80 & & $0.063(0.06)$ & $1.00(0.37)$ \\
\hline & low $\mathrm{P} /$ high $\mathrm{P}$ & & 3.01 & 1.05 \\
\hline & 4 & 30 & $0.108(0.01)$ & $0.404(0.01)$ \\
\hline & 80 & & $0.097(0.04)$ & $0.230(0.00)$ \\
\hline & low $\mathrm{P} /$ high $\mathrm{P}$ & & 1.11 & 1.76 \\
\hline
\end{tabular}

$a_{\mathrm{ND}}=$ not detectable.

The release rates of citric and piscidic acids were expressed as the amount $(\mu \mathrm{mol})$ of the release to total root dry weight $(\mathrm{g})$. The external $\mathrm{P}$ concentration in the low-P treatment was increased to $4 \mu \mathrm{M}$ to prevent the plants from dying of severe $\mathrm{P}$ deficiency after 15 days. Values are means $(n=2)$ with standard error in parentheses. The values of low $\mathrm{P} /$ high $\mathrm{P}$ express the ratio of the release rates in low $\mathrm{P}$ treatment $(2$ or $4 \mu \mathrm{M} \mathrm{P})$ to that in high $\mathrm{P}(80 \mu \mathrm{M} \mathrm{P})$ treatment. 

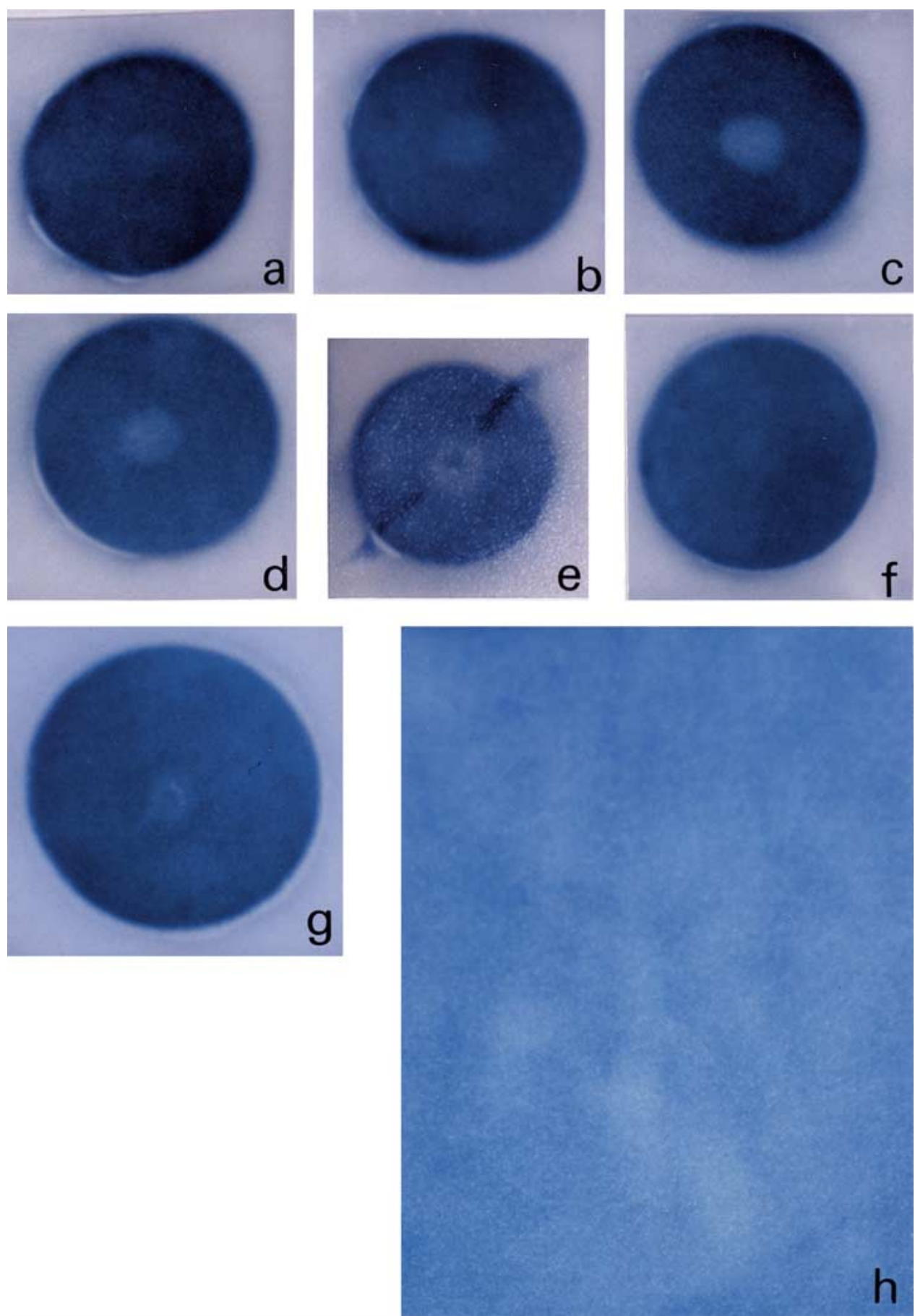

Figure 3. Fe-P solubilizing activity of carboxylic acids, root exudates, and its release portion. (a) control, (b) $5 \mathrm{mM}$ citric acid, (c) $100 \mathrm{mM}$ citric acid, (d) $100 \mathrm{mM}$ malic acid, (e) $100 \mathrm{mM}$ piscidic acid, (f) $0.5 \mathrm{M}$ succinic acid, (g) root exudates collected from Manak roots after low-P treatment $(2 \mu \mathrm{M})$ for 30 days, (h) the roots of Manak treated with low-P for 30 days were placed on the filter paper containing $\mathrm{FePO}_{4}$ solution. After $24 \mathrm{~h}$, the paper was stained with molybdenum-ascorbic acid. Intensive white spots indicate where the root tips were placed. 
Table 3. Change in the release rates of citric and piscidic acids depending on change in internal $\mathrm{P}$ concentration

\begin{tabular}{|c|c|c|c|c|c|c|}
\hline \multirow[t]{2}{*}{ Genotype } & \multirow{2}{*}{$\frac{\mathrm{P} \text { treatment }^{a}}{(\mu \mathrm{M} \mathrm{P})}$} & \multirow{2}{*}{$\frac{\text { Period }}{\text { (days) }}$} & Citric acid & Piscidic acid & Shoot & Root \\
\hline & & & \multicolumn{2}{|c|}{$\left(\mu \mathrm{mol} \mathrm{g}^{-1}\right.$ root dry wt $\left.24 \mathrm{~h}^{-1}\right)$} & \multicolumn{2}{|c|}{$\left(\mathrm{mg} \mathrm{P} \mathrm{g}^{-1}\right.$ dry wt $)$} \\
\hline \multirow[t]{3}{*}{ ICPH 8} & $\mathrm{~L}$ & 15 & $0.058(0.03)$ & $1.63(0.10)$ & $1.80(0.16)$ & $3.81(0.42)$ \\
\hline & L-L & $15-7$ & $0.069(0.01)$ & $4.30(1.24)$ & $1.92(0.15)$ & $4.69(0.91)$ \\
\hline & L-H & $15-7$ & $0.041(0.01)$ & $2.45(0.05)$ & $6.58(0.31)$ & $9.54(0.76)$ \\
\hline \multirow[t]{3}{*}{ ICPL 87} & $\mathrm{~L}$ & 15 & $0.045(0.03)$ & $1.42(0.11)$ & $1.90(0.22)$ & $6.37(0.80)$ \\
\hline & L-L & $15-7$ & $0.048(0.02)$ & $2.90(0.67)$ & $1.78(0.01)$ & $6.14(0.69)$ \\
\hline & L-H & $15-7$ & $0.029(0.01)$ & $2.26(0.47)$ & $6.65(1.12)$ & $9.78(0.61)$ \\
\hline \multirow[t]{3}{*}{ Manak } & $\mathrm{L}$ & 15 & $0.085(0.04)$ & $2.12(0.07)$ & $1.89(0.40)$ & $5.38(1.02)$ \\
\hline & L-L & $15-7$ & $0.048(0.00)$ & $5.54(0.17)$ & $1.49(0.23)$ & $6.83(0.56)$ \\
\hline & L-H & $15-7$ & $0.057(0.01)$ & $4.72(0.23)$ & $5.74(0.46)$ & $8.89(0.31)$ \\
\hline \multirow[t]{3}{*}{ ICPL 88039} & $\mathrm{~L}$ & 15 & $0.063(0.01)$ & $1.63(0.10)$ & $1.82(0.22)$ & $6.07(0.92)$ \\
\hline & L-L & $15-7$ & $0.049(0.00)$ & $5.23(0.30)$ & $1.74(0.04)$ & $6.56(0.78)$ \\
\hline & L-H & $15-7$ & $0.026(0.01)$ & $2.89(0.50)$ & $7.20(0.47)$ & $7.85(0.37)$ \\
\hline
\end{tabular}

$\bar{a}$ Seedlings pre-exposed to $2 \mu \mathrm{M}$ P for 15 days $(\mathrm{L}, 15)$ were transferred to the $2(\mathrm{~L}-\mathrm{L})$ or $80 \mu \mathrm{M} \mathrm{P}(\mathrm{L}-\mathrm{H})$ and then treated for more 7 days $(15-7)$. Values are means $(n=2-3)$ with standard error in parentheses.

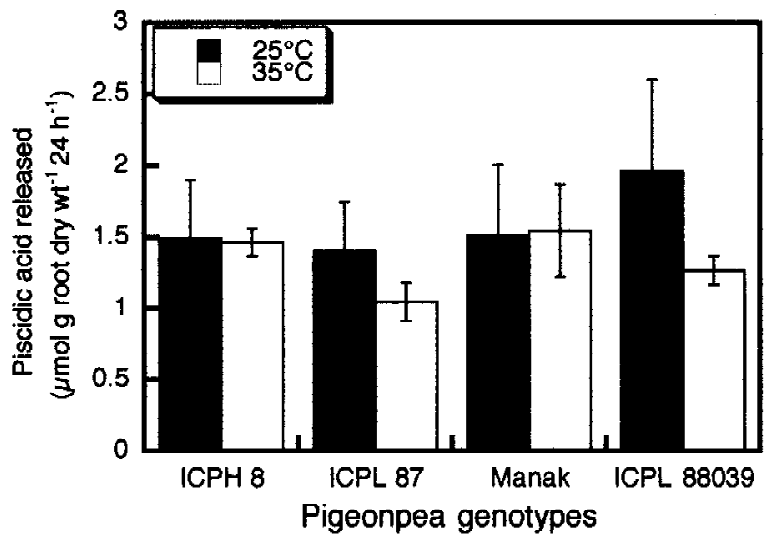

Figure 4. Effect of temperature on piscidic acid release from roots. After 15 days at low-P treatment, seedlings were transferred to container containing $1 \mathrm{mM} \mathrm{CaCl} 2$ solution. Root exudates were collected and put into two water baths that were continuously maintained at $25{ }^{\circ} \mathrm{C}$ or $35^{\circ} \mathrm{C}$. The columns and vertical bars represent the means and the standard errors from two replications.

roots between treatments or among genotypes (data not shown). The release of piscidic acid from roots increased remarkably in all the genotypes after continuous treatment with the same low $\mathrm{P}$ concentration $(2 \mu \mathrm{M})$ for 7 days (L-L) following low-P pretreatment for 15 days (L), but the $\mathrm{P}$ concentrations in shoots and roots remained similar despite this increase in piscidic acid exudation (Table 3 ). The $\mathrm{P}$ concentra- tions in shoots and roots increased remarkably with increasing external $\mathrm{P}$ concentration, and the release rate of citric acid decreased in all the genotypes. On the other hand, the release of piscidic acid did not decrease but was rather enhanced as compared with that of 15 days at low-P treatment. Two temperature treatments $\left(25^{\circ} \mathrm{C}\right.$ and $\left.35^{\circ} \mathrm{C}\right)$ had no significant effect on the release of piscidic acid by genotypes although the release from ICPL 87 and ICPL 88039 decreased at $35^{\circ} \mathrm{C}$ (Figure 4).

Among the four organic acids, citric acid was most able to dissolve insoluble $\mathrm{P}$ in the Alfisol (Figure 5). Succinic acid could hardly dissolve insoluble $\mathrm{P}$ even at a high concentration. Piscidic acid had higher solubilizing ability than malic acid. At least $100 \mu \mathrm{M}$ of any organic acid was required to release $1.6 \mu \mathrm{M}$ P of insoluble $\mathrm{P}$ in the Alfisol into the soil solution.

\section{Discussion}

Ae et al. (1990) first reported that pigeonpea exuded piscidic acid from roots under low available $\mathrm{P}$ conditions. This is a unique carboxylic acid detected mainly in pigeonpea and there are no reports of its occurrence in other plants. Piscidic acid was identified in root exudates of all pigeonpea genotypes tested in this study, irrespective of external P levels (Table 2). Pis- 


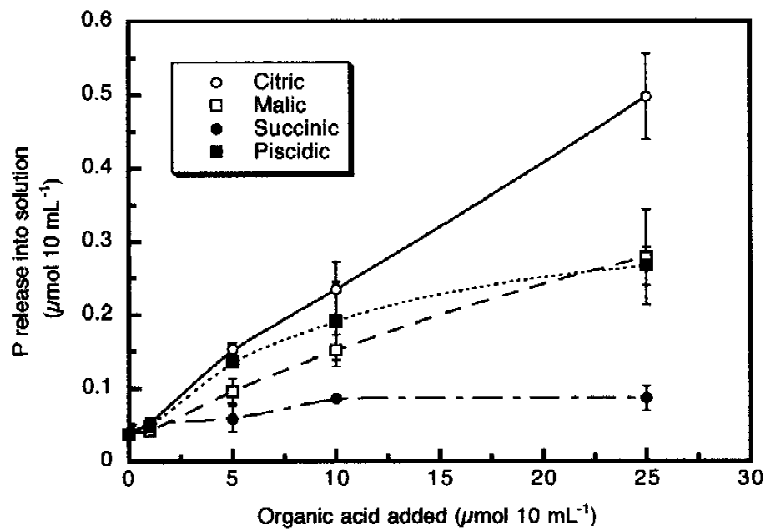

Figure 5. Extraction efficiency of insoluble P from an Alfisol by four organic acids. The $\mathrm{P}$ concentration in solution was assessed by extracting the Alfisol with each organic acid solution ( $\mathrm{pH} 4.5)$ for $60 \mathrm{~min}$. The values represented are the means and standard errors from six replications.

cidic acid was also observed in root exudates of four other pigeonpea genotypes in addition to those shown in Table 2 (data not shown). The release of piscidic acid was enhanced by low-P conditions (Table 2 ) and increased with extended severe low-P treatment period (Table 3). These findings suggest that piscidic acid release from roots is a general characteristic of pigeonpea, and that its release is induced more by $\mathrm{P}$ deficiency. Citric acid release also was induced by low-P treatment, but the amount released was approximately $1 / 5-1 / 100$ that of piscidic acid (Tables 2 and $3)$. Citric acid was better able to dissolve Fe-P than piscidic acid (Figures 3 and 5). However, citric acid seemed to have a lesser role in solubilizing Fe-P by pigeonpea root exudates (Figure $3 \mathrm{~g}$, h) than piscidic acid because of it is only released in very small amounts (Tables 2 and 3).

The release of citric and piscidic acids depended on internal $\mathrm{P}$ concentration, especially that in shoots (Table 3). In addition, piscidic acid release increased without further decreasing in the $\mathrm{P}$ concentrations in shoots and roots. This result suggests that piscidic acid release from the roots might depend on low$\mathrm{P}$ treatment period and plant age besides internal $\mathrm{P}$ concentration (Otani and Ae, 1997). The release of piscidic acid was enhanced regardless of the significant increase in $\mathrm{P}$ concentration of shoots after high$\mathrm{P}$ treatment following low-P pretreatment (Table 3). This suggests that inducible piscidic acid synthesis may be involved in its release from pigeonpea roots as shown in the release pattern of citric acid from roots of Cassia tora L. in response to Al toxicity where a significant secretion of citric acid was induced by $6 \mathrm{~h}$ without Al after 3-h pulse with Al (Ma et al., 1997). The mechanisms of synthesis and release of piscidic acid from pigeonpea roots need further investigation. The release of piscidic acid in all the genotypes tested was hardly affected by the comparatively high temperature of $35^{\circ} \mathrm{C}$, a temperature to be expected in soils in tropical areas (Figure 4). Therefore, piscidic acid exudation was thought to be a specific response to $\mathrm{P}$ deficiency in shoots.

Genotypic variability in the release rate of piscidic acid from roots was not found among pigeonpea genotypes, but the releases from Manak and ICPL 88039 were a little higher than those from the other two genotypes under low-P treatment throughout this study (Tables 2 and 3, Figure 4). Jones (1998) pointed out that organic acid release rates calculated based on total root mass are greatly underestimated, and that weight ratio between treatments can severely bias the results. The Fe-P solubilizing substances were localized to root-tips (Figure 3h), corresponding with the findings of Hoffland et al. (1989) who observed rhizosphere acidification of the root-tips of rape under P-stressed conditions. This study had no alternative but to express the exudates in terms of total root mass due to the difficulty of collecting root-tips. Small difference in the release rate of piscidic acid among genotypes in low-P treatment may be attributed to calculation based on total root dry mass. Phosphorus deficiency significantly increases the leakage of the plasma membrane because of the decrease in the level phospholipids (Ratnayake et al., 1978). Therefore, the approximately 2- or 3-fold increase in piscidic and citric acids in the low-P treatment shown in Table 2 might not indicate an active release implicated in the $\mathrm{P}$ acquisition, but a secondary root response.

Pigeonpea could utilize sparingly soluble $\mathrm{P}$ sources, irrespective of genotype (Figure 1a, b). This is thought to be efficient utilization of available $\mathrm{P}$ quantified by the Bray II method (Table 1). The greater dry matter production and $\mathrm{P}$ uptake of Manak at $\mathrm{P}_{0}$ and Fe-P application than those of the other genotypes were presumed to be due to its superior ability in Fe$\mathrm{P}$ utilization (Figure 1a, b). The dry weight and $\mathrm{P}$ uptake of ICPL 88039 were considerably lower than Manak under $\mathrm{P}_{0}$ application, although the amount of piscidic acid released from the roots of ICPL 88039 was comparable to that of Manak. This result suggests that Manak might have another mechanism (s) related to $\mathrm{P}$ acquisition and utilization from low-P availability soils in addition to piscidic acid release. 
Solubilization of $\mathrm{P}$ compounds in the soil by organic acids is achieved by the replacement between organic acids and $\mathrm{P}$ on the ligand exchange surface and by formation of complexes between organic acids and metal ions such as $\mathrm{Fe}, \mathrm{Al}$ and $\mathrm{Ca}$. Complex formation depends on the number and position of carboxyl $(-\mathrm{COOH})$ and hydroxyl $(-\mathrm{OH})$ functional groups in the organic acids (Hue et al., 1986). Solubilization of P by several organic acids from Alfisol where the Fe-bound $\mathrm{P}$ dominates corresponded to the stability constant for Al $\left(\log K_{A l} ; 12.26\right.$ for citric acid, 6.21 for tartaric acid, 6.00 for malic acid, and 4.62 for succinic acid, cited in the data of Hue et al., 1986) (Figure 5). This also was confirmed by the assay method for Fe-P solubilizing activity (Figure 3 ). The stability constant for $\mathrm{Fe}^{3+}$ is comparable to that of $\mathrm{Al}^{3+}$ for citric and malic acids (Cline et al., 1982). The stability constant of Fe-piscidic acid is predicted to be similar to that of Fe-tartaric acid because carboxyl and hydroxyl groups of the tartarate portion of piscidic acid are involved in chelation of $\mathrm{Fe}^{3+}$ (Ae et al., 1990).

It remains unknown whether the amount of organic acid released from the roots is sufficient to dissolve sparingly soluble $\mathrm{P}$ in soils, thereby enabling to survive and alleviate $\mathrm{P}$ deficiency. The total amount of citric and piscidic acids released from pigeonpea roots was in the range of $0.1-0.7 \mu \mathrm{mol}$ plant $^{-1} 24 \mathrm{~h}^{-1}$ depending on $\mathrm{P}$ stress status, and its amount was considerably lower than the amounts of citric (25$175 \mu$ mol plant ${ }^{-1} 24 \mathrm{~h}^{-1}$ ) and malic (25-200 $\mu \mathrm{mol}$ plant $^{-1} 24 \mathrm{~h}^{-1}$ ) acids released from P-deficient Lipinus albus (Johnson et al., 1996). In addition, the amount was not sufficient to extract insoluble $\mathrm{P}$ in Alfisols (Figure 5) even if the root exudates collected from Manak could solubilize the Fe-P on filter paper (Figure $3 \mathrm{~g}$ ). The concentration of organic acids at the root surface is predicted by a simulation model based on data of organic acid efflux in bulk solution (Jones et al., 1996a; Pellet et al., 1997; Ryan et al., 1995). Sorption of organic acids to a soil's solid phase (Hue, 1991) and degradation by micro-organisms (Jones et al., 1996b) are important factors to be considered when estimating the concentration of organic acids at the root surface. Figure 5 indicates that the concentration of organic acids at the pigeonpea root surface would need to be more than $100 \mu \mathrm{M}$ to mobilize $\mathrm{P}$ in Alfisols. The real concentration of organic acids at the root surface will need to be measured when a crop is growing.

In conclusion, we could not explain the difference in the plant growth and the $\mathrm{P}$ uptake among pigeon- pea genotypes grown in an Alfisol through the citric and piscidic acids released from their roots. However, there is need of a similar research using a large number pigeonpea genotypes. The filter paper technique demonstrated in Figure 3 might be useful as a rapid and simple screening system for identifying those genotypes effective in extracting $\mathrm{P}$ by root exudates from a large number of genotypes. An increase in $\mathrm{P}$ available in an Alfisol was observed after cultivation of pigeonpea without application of $\mathrm{P}$ (Figure 2). This finding indicates the possibility that pigeonpea may be a leguminous crop effective in enhancing soil fertility.

\section{Acknowledgements}

We are grateful to all the supporting staff of the Project funded by the Government of Japan for their help with the experiments.

\section{References}

Adu-Gyamfi J J, Ishikawa S, Nakamura T and Nakano H 2000 Genotypic variability and physiological characteristics of crop plants adapted to low-nutrient environments. In Food Security in Nutrient-Stressed Environments: Exploiting Plants' Genetic Capabilities, Proceedings of an International Workshop 27-30 September 1999, Patancheru, India. Developments in Plant and Soil Sciences volume 94. Ed. J J Adu-Gyamfi. Kluwer Academic Publishers, Dordrecht, The Netherlands. (in press).

Ae N, Arihara J, Okada K, Yoshihara T and Johansen C 1990 Phosphorus uptake by pigeonpea and its role in cropping systems of the Indian subcontinent. Science 248, 477-480.

Cline G R, Powell, P E, Szaniszlo P J and Reid C P P 1982 Comparison of the abilities of hydroxamic, synthetic and other natural organic acids to chelate iron and other ions in nutrient solution. Soil Sci. Soc. Am. J. 46, 1158-1164.

Fujita K, Chaudhary M I, Adu-Gyamfi J J and Yoshizawa D 1995 Dinitrogen fixation and growth responses to phosphorus and aluminum application in pigeon pea (Cajanus cajan L.). Soil Sci. Plant Nutr. 41, 729-735.

Gardner W K, Barber D A and Parberry D G 1983 The acquisition of phosphorus by Lupinus albus L. III. The probable mechanism by which phosphorus movement in the soil/root interface in enhanced. Plant Soil 70, 107-124.

Hoffland E 1992 Quantitative evaluation of the role of organic acid exudation in the mobilization of rock phosphate by rape. Plant Soil 140, 279-289.

Hoffland E, Findenegg G R and Nelemans J A 1989 Solubilization of rock phosphate by rape. II. Local root exudation of organic acids as a response to P-starvation. Plant Soil 113, 161-165.

Hue N V 1991 Effects of organic acids/anions on P sorption and phytoavailability in soils with different mineralogies. Soil Sci. $152,463-471$.

Hue N V, Craddock G R and Adams F 1986 Effect of organic acids on aluminum toxicity in subsoils. Soil Sci. Soc. Am. J. 50, 2834. 
Johnson J F, Vance C P and Allan D L 1996 Phosphorus deficiency in Lupinus albus. Altered lateral root development and enhanced expression of phosphoenolpyruvate carboxylase Plant Physiol. 112, 31-41.

Jones D L 1998 Organic acids in the rhizosphere - a critical review. Plant Soil 205, 25-44.

Jones D L and Darrah P R 1994 Role of root derived acids in the mobilization of nutrient from the rhizosphere. Plant Soil 166, 247-257.

Jones D L, Darrah P R and Kochian L V 1996a Critical evaluation of organic acid mediated iron dissolution in the rhizosphere and its potential role in root iron uptake. Plant Soil 180, 57-66.

Jones D L, Prabowo A M and Kochian L V 1996b Kinetics of malate transport and decomposition in acid soils and isolated bacterial populations: The effect of microorganisms on root exudation of malate under Al stress. Plant Soil 182, 239-247.

Ma J F, Zheng S J and Matsumoto H 1997 Specific secretion of citric acid induced by Al stress in Cassia tora L. Plant Cell Physiol. 38, 1019-1025.

Murphy J and Riley J P 1962 A modified single solution method for the determination of phosphate in natural waters. Anal. Chem. Acta 27, 31-36.

Ohwaki Y and Hirata H 1992 Difference in carboxylic acid exudation among P-starved leguminous crops in relation to carboxylic acid contents in plant tissues and phospholipid level in roots. Soil Sci. Plant Nutr. 38, 235-243.

Otani T and Ae N 1997 The exudation of organic acids by pigeonpea roots for solubilizing iron- and aluminum-bound phosphorus. In Plant Nutrition-for Sustainable Food Production and Environment. Eds T Ando, K Fujita, T Mae, H Matsumoto, S Mori and J Sekiya. pp. 325-326. Kluwer Academic Publishers, Dordrecht, The Netherlands.

Pellet D M, Paperinik L A, Jones D L, Darrah P R, Grunes D L and
Kochian L V 1997 Involvement of multiple aluminium exclusion mechanisms in aluminium tolerance in wheat. Plant Soil 192, 63-68.

Ratnayake M, Leonald R T and Menge J A 1978 Root exudation in relation to supply of phosphorus and its possible relevance to mycorrhizal formation. New Phytol. 81, 543-552.

Rengel Z 1999 Physiological mechanisms underlying differential nutrient efficiency of crop genotypes. In Mineral Nutrition of Crops: Mechanisms and Implications. Ed. Z Rengel. pp. 227265. The Haworth Press, New York.

Ryan P R, Delhaize E and Randall P J 1995 Malate efflux root apices and tolerance to Aluminium are highly correlated in wheat. Aust. J. Plant Physiol. 22, 531-536.

Sekiya K 1983 Fractionation of soil inorganic phosphorus. In Methods of Soil Analysis. Ed. Dojo Yobun Bunsekihou. pp. 235-238. Yokendo, Tokyo, Japan (in Japanese).

Subbarao G V, Ae N and Otani T 1997a Genetic variation in acquisition, and utilization of phosphorus from iron-bound phosphorus in pigeonpea. Soil Sci. Plant Nutr. 43, 511-519.

Subbarao G V, Ae N and Otani T 1997b Genetypic variation in ironand aluminum-phosphate solubilizing activity of pigeonpea root exudates under P deficient conditions. Soil Sci. Plant Nutr. 43, 295-305.

Toshima H, Saito M and Yoshihara T 1999 Total synthesis of (+)$(2 S, 3 R)$-piscidic acid via catalytic asymmetric dihydroxylation of a trisubstituted olefin. Biosci. Biotechnol. Biochem. 63, 964967.

Yoshihara T, Ichihara A and Sakamura S 1971 The synthesis of dimethyl esters of $d l-O, O^{\prime}$-dimethylfukiic acid and $d l-O$, $O^{\prime}$-dimethylepifukiic acid. Agr. Biol. Chem. 35, 1822-1824.

Zheng S J, Ma J F and Matsumoto H 1998 High aluminum resistance in buckwheat. I. Al-induced specific secretion of oxalic acid from root tips. Plant Physiol. 117, 745-751. 